\title{
STRATEGI PEMASARAN SYARIAH DAN WAITING LIST TERHADAP KEPUTUSAN NASABAH MENGGUNAKAN PRODUK TABUNGAN HAJI PADA PT BRISYARIAH KCP GENTENG KABUPATEN BANYUWANGI
}

\author{
Nur Anim Jauhariyah; Ahmad Munawar; Mahmudah \\ Institut Agama Islam Darussalam (IAIDA) Blokagung Banyuwangi \\ animjauhariyah@gmail.com, Nawar0797@gmail.com, \\ mahmudah.ahmadd@gmail.com
}

\begin{abstract}
The purpose of this study is 1) to find out and analyze the influence of sharia marketing strategy (X1) on customer decisions (Y) using Hajj savings products in BRISyariah KCP Genteng Banyuwangi district; 2) to find out and analyze the influence of the waiting list (X2) on the customer's decision (Y) to use the Hajj savings product at BRISyariah KCP Genteng Banyuwangi district; 3 ) to find out and analyze the influence of sharia marketing strategy (X1) and waiting list (X2) simultaneously on the customer's decision (Y) to use Hajj savings products in BRISyariah KCP Genteng Banyuwangi district. The research method is quantitative with the type of survey research. Research Results 1) there is a significant influence of sharia marketing strategy (X1) on the customer's decision (Y) to use the Hajj savings product at BRISyariah KCP Genteng Banyuwangi district; 2) there is no significant influence of the waiting list (X2) on the customer's decision $(\mathrm{Y})$ to use the Hajj savings product at BRISyariah KCP Genteng Banyuwangi district; 3) there is a significant influence of sharia marketing strategy (X1) and waiting list (X2) simultaneously on the customer's decision (Y) to use Hajj savings products in BRISyariah KCP Genteng Banyuwangi district. Marketing and waiting list strategies are not dominant in influencing prospective customers to use Hajj savings products. The influence exerted was only $41 \%$.
\end{abstract}

Keywords: Sharia Marketing Strategy, Waiting List, and Customer Decisions

\section{Pendahuluan}

Menunaikan ibadah haji merupakan salah satu dari lima rukun islam yang wajib dilaksanakan oleh setiap muslim yang telah mampu baik lahir maupun bathin. Kewajiban tersebut dapat dilihat dari beberapa ayat dalam al Qur'an, salah satu ayat Al Qur'an yang mewajibkan untuk melaksanakan ibadah haji yaitu QS Al Hajj ayat 27 yang berbunyi:

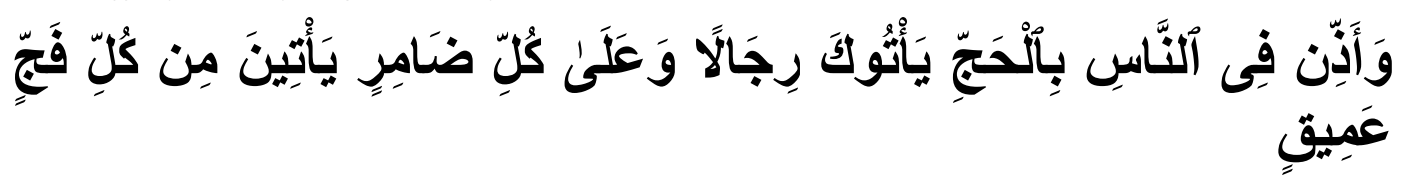

Artinya : "Dan berserulah kepada manusia untuk mengerjakan haji, niscaya mereka akan datang kepadamu dengan berjalan kaki, dan 
mengendarai unta yang kurus yang datang dari segenap penjuru yang jauh."'(QS: Al-Hajj[22] :27).

Ayat al Qur'an di atas menjelaskan bahwa perintah untuk menyerukan kepada semua umat islam tentang kewajiban menunaikan ibadah haji di Baitullah serta menjelaskan tentang segala keutamaan bagi orang yang melaksanyakannya. Selain ayat al Qur'an, dalam hadits Nabi juga dijelaskan tentang kewajiban menunaikan ibadah haji bagi setiap muslim yang telah mampu menunaikannya seperti sudah baligh dan cukup secara finansial, fisik dan mental. Seperti hadits yang di riwayatkan oleh Imam Bukhari dan Muslim dari Abu Hurairah:

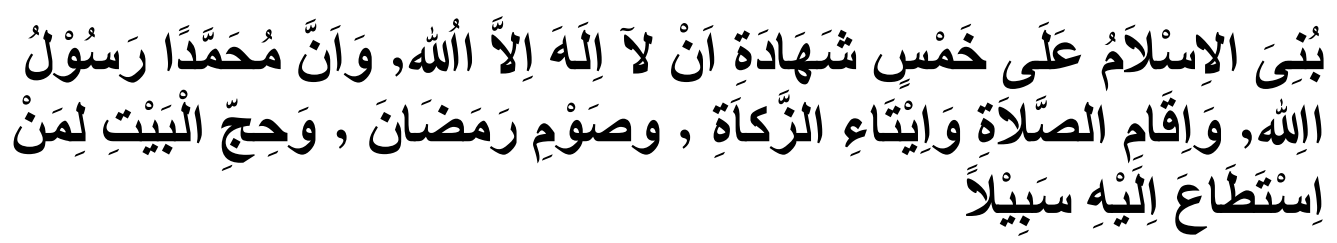

Artinya :"Agama islam dibangun atas lima yatiu bersaksi bahwa tiada Tuhan yang wajib disembah kecuali Allah dan bersaksi bahwa Nabi Muhammad adalah utusan Allah, mendirikan sholat 5 waktu, membayar zakat, puasa di Bulan Ramadhan, dan melaksanakan Haji ke Baitullah bagi orang-orang yang mampu melaksanakannya”.(HR Bukhori Muslim)

Hadits di atas menjelaskan tentang lima rukun dalam Islam yang wajib dilaksanakan oleh setiap umat Islam, salah satunya adalah menunaikan ibadah haji ke Baitullah bagi umat Islam yang telah mampu melaksanakannya. Ibadah haji hanya wajib dilakukan sekali seumur hidup oleh umat muslim di dunia. Kegiatan melaksanakan Ibadah haji hanya dilakukan ketika bulan haji saja yaitu bulan Dzulhijjah.

Ibadah haji merupakan salah satu ibadah dalam Islam yang wajib dilaksanakan bagi seluruh umat Islam yang telah mampu, baik mampu secara materi maupun mampu secara fisik. Kedua hal itu (fisik dan materi) menjadi penting karena dalam melaksanakan ibadah haji diperlukan fisik atau badan yang sehat, hal ini berkenaan dengan banyaknya rukun ibadah haji yang harus dilaksanakan. Selain dari kemampuan fisik, ibadah haji juga memerlukan biaya untuk memenuhi semua kebutuhan selama melaksankan ibadah haji di tanah suci Makkah, seperti ongkos keberangkatan ataupun biaya-biaya lainnya. Salah 
satu cara yang bisa dilakukan adalah dengan menabung sedikit demi sedikit dalam jangka waktu yang cukup lama agar bisa mendaftar menjadi calon jama'ah haji. Sebagaimana rukun Islam yang kelima yaitu kewajiban menjalankan ibadah haji bagi yang telah mampu. Mampu disini bisa diartikan tidak hanya mampu secara fisik, tetapi mampu juga secara finansial. ${ }^{1}$

Antusiasme masyarakat dalam melaksanakan ibadah haji sangat besar, maka Dewan Syariah Nasional memberikan peluang kepada lembaga keuangan syariah untuk merespon kebutuhan masyarakat dalam memenuhi kebutuhan haji, dengan mengeluarkan Fatwa DSN No. 29/DSNMUI/VI/2002 tentang pembiayaan pengurusan haji lembaga keuangan syariah pada ketentuan umum pertama angka satu bahwa pengurusan haji bagi nasabah, LKS dapat memperoleh imbalan jasa (ujroh) dengan menggunakan prinsip al ijaroh sesuai Fatwa DSN MUI No. 09/DSNMUI/IV/2000. ${ }^{2}$

Bank Rakyak Indonesia Syariah memiliki banyak sekali produk-produk baik simpanan maupun pinjaman sesuai dengan kebutuhan masyarakat. Salah satu produk tabungan Bank Rakyat Indonesia Syariah adalah produk tabungan haji BRISyariah. Tabungan Haji BRISyariah merupakan salah satu produk tabungan berjangka BRISyariah yang dirancang untuk nasabah dalam memenuhi kebutuhan Biaya Perjalanan Ibadah Haji (BPIH). Akad yang digunakan dalam Tabungan Haji BRISyariah adalah Mudharabah Muthlaqah . ${ }^{3}$ Strategi pemasaran yang digunakan BRISyariah dengan menyebarkan brosur kepada masyarakat, memasang spanduk, serta standing banner, bekerjasama dengan biro travel haji, memberikan souvenir kepada calon jamaah haji, serta melakukan promosi melalui media elektronik. ${ }^{4}$

1 Daulay, Aqwa Naser. 2017. Faktor-Faktor Yang Berhubungan Dengan Perkembangan Produk Tabungan Haji Perbankan Syariah Di Indonesia Human Falah. Sumatra Utara. Fakultas Ekonomi dan Bisnis Islam UIN Sumatra Utara. Hal. 105-106

2 Dewi, Rida Arista. 2018. Pengaruh Pendapatan, Religiuistas dan Daftar Tunggu Haji Terhadap Minat Santri Untuk Menabung Tabungan Haji dengan Pendekatan Theory of Planned Behavior. Skripsi. Yogyakarta: Fakultas Ekonomi dan Bisnis Islam UIN Sunan Kalijaga Yogyakarta.Hal 4

3 Tim BRISyariah. 2019. Profil BRISyariah Indonesia. (online). www.BRISyariah.com

4 Tajudin, Makdaleva, Hanura., Mulazid, Ade, Sofyan. 2017. Pengaruh Promosi, Kepercayaan Dan Kesadaran Merek Terhadap Keputusan Nasabah Menggunakan Produk 
Bank Rakyat Indonesia Syariah akan melakukan segala upaya dalam memasarkan dan mengenalkan produk tabungan haji BRISyariah iB tersebut kepada masyarakat. Bank Rakyat Indonesia Syariah sangat memperhatikan strategi yang digunakan dalam mengenalkan tabungan haji kepada masyarakat mengingat persaingan yang semakin ketat sehingga menuntut lembaga keuangan syariah ini berfikir lebih kreatif dalam menerapkan strategi khususnya pada produk tabungan haji. BRISyariah dituntut untuk terus melakukan pemasaran yang lebih baik. Untuk dapat selalu memenuhi pangsa pasar yang terus mengalami peningkatan, maka BRISyariah menerapkan berbagai strategi untuk mengenalkan kepada masyarakat tentang tabungan haji yaitu dengan melengkapi infrastruktur. ${ }^{5}$

Kuota haji merupakan daftar tunggu keberangkatan jamaah haji setalah terdaftar sebagai calon jamaah haji. Mengenai mengapa orang yang telah mendaftar haji tetapi baru dapat berangkat haji setelah bertahun tahun, hal ini dikarena adanya kuota haji. Maka semua orang tidak dapat langsung berangkat haji pada tahun berjalan dikarenakan panjangnya daftar tunggu atau antrian di Indonesia atau yang sering disebut dengan waiting list. Waiting list merupakan problem yang menjadi keluhan bagi para calon jamaah haji (Ermawati, 2018:22). Tujuan Penelitian yaitu a) Menganalisis pengaruh strategi pemasaran syariah terhadap keputusan nasabah untuk menggunakan tabungan haji di BRISyariah KCP Genteng Kabupaten Banyuwangi; b) Menganalisis pengaruh waiting list terhadap keputusan nasabah untuk menggunakan tabungan haji di BRISyariah KCP Genteng Kabupaten Banyuwangi. c) Menganalisis pengaruh strategi pemasaran syariah dan waiting list secara simultan terhadap keputusan nasabah untuk menggunakan tabungan haji di BRISyariah KCP Genteng Kabupaten Banyuwangi.

Tabungan Haji (Mabrur) Bank Syariah Mandiri Kcp. Sawangan Kota Depok Jurnal Ekonomi Islam. Hal 21

${ }^{5}$ Ardiastuti, Wiji. T: 2017. Strategi Pemasaran Tabungan Haji Di Bank Rakyat Indonesia Syariah Kcp Ajibarang. Purwokerto: Fakultas Ekonomi dan Bisnis Islam IAIN Purwokerto. Hal 12 


\section{Landasan Teori}

\section{Manajemen Pemasaran}

Manajemen pemasaran merupakan sistem total aktivitas bisnis yang dirancang untuk merencanakan, menetapkan harga, dan mendistribusikan produk, jasa dan gagasan yang mampu memuaskan keinginan pasar sasaran dalam rangka mencapai tujuan organisasional. ${ }^{6}$

Pemasaran adalah suatu fungsi organisasi dan serangkaian proses untuk menciptakan, mengkomunikasikan, dan memberikan nilai kepada pelanggan dan untuk mengelola hubungan pelanggan dengan cara yang menguntungkan organisasi dan pemangku kepentingannya. ${ }^{7}$

\section{Strategi Pemasaran Syariah}

Konsep pemasaran syariah sebenarnya tidak jauh berbeda dengan pemasaran yang dikenal, perbedaannya dalam syariah mengajarkan pelakunya bersikap jujur kepada konsumen. Tujuh konsep dalam bauran pemasaran yaitu : Product (Produk), Place (Tempat), Price (Harga), dan Promotion (Promosi), people (Orang), Process (Proses) dan Physical Evidence (Bukti Fisik). ${ }^{8}$

Agama Islam mengajarkan kita untuk selalu bersikap jujur dan tidak melakukan kecurangan. Sebagaimana firman Allah SWT:

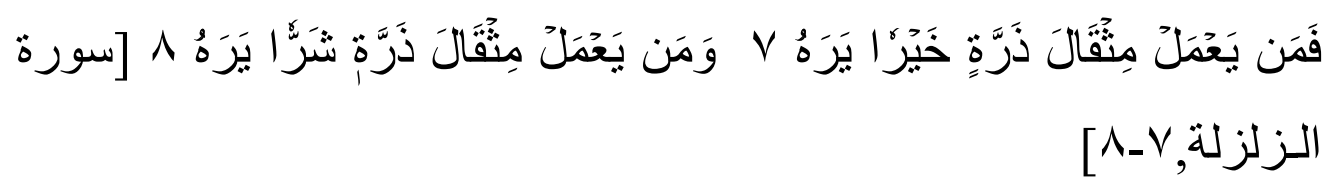

Artinya: "Barang siapa yang mengerjakan kebaikan walaupun sebesar biji dzarrah, niscaya dia akan melihat (balasan)nya. Dan barang siapa yang mengerjakan kejahatan walupun sebesar biji dzarrah, niscaya dia akan melihat (balasan)nya pula”. (Q.S. Al-Zalzalah: 7-8)

${ }^{6}$ Fandy Tjiptono. 2015. Strategi Pemasaran. Yagyakarta: Penerbit Andi. Hal. 2

7 Kotler, Philip dan Keller, K.L. 2016. Manajemen Pemasaran, Edisi 13 Jilid 1. Jakarta:Penerbit Erlangga. Hal 5

${ }^{8}$ Kotler, Philip, dan Gary Armstrong. 2012. Prinsip-prinsip Pemasaran, Edisi 13 Jilid 1. Jakarta: Penerbit Erlangga. Hal 78 


\section{Waiting List}

Kuota haji merupakan batasan jumlah calon jamaah haji Indonesia yang ditetapkan oleh pemerintah kerajaan Arab Saudi berdasarkan hasil ketetapan Organisasi Konferensi Islam tahun 1987, yaitu satu perseribu dari jumlah penduduk muslim masing-masing negara, karena adanya ketetapan kuota haji, maka tidak semua calon jamaah haji dapat langsung menunaikan ibadah haji pada tahun berjalan, karena tidak seimbang antara jumlah calon jamaah haji yang mendaftar dengan calon jamaah haji yang akan berangkat tiap tahunnya, mereka harus menunggu terlebih dahulu bertahun-tahun. ${ }^{9}$

\section{Keputusan Nasabah}

Keputusan nasabah dalam mengambil biaya dari perbankan untuk pemberangkatan haji dalam hal ini dikaitkan dengan teori perilaku konsumen dipengaruhi oleh beberapa indikator yaitu: Indikator Budaya, Indikator Keluarga, Indikator Peran dan Status, Indikator Pribadi dan Indikator Psikologis. ${ }^{10}$ Sedangkan proses pengambilan keputusan pembelian terdiri dari lima proses konsumen. Adapun lima proses tersebut adalah: 1) Problem recognition (Pengakuan Masalah); 2) Information search (Pencarian Informasi); 3) Evaluasi alternatif; 4) Keputusan pembeli dan 5) Perilaku pasca pembelian. ${ }^{11}$

${ }^{9}$ Ermawati. 2018. Analisis Dampak Implementasi Produk Tabungan Haji Mabrur Terhadap Waiting List Ibadah Haji. Skripsi. Lampung: Fakultas Ekonomi dan Bisnis Islam UIN Raden Intan Lampung.Hal 83

${ }^{10}$ Kotler, Philip, dan Gary Armstrong. 2012. Prinsip-prinsip Pemasaran, Edisi 13 Jilid 1. Jakarta: Penerbit Erlangga. Hal 78.Hal 62-64

${ }^{11}$ Kotler, Philip dan Keller, K.L. 2016. Manajemen Pemasaran, Edisi 13 Jilid 1. Jakarta:Penerbit Erlangga. Hal 195 


\section{Metode Penelitian}

\section{Jenis Penelitian}

Jenis penelitian ini menggunakan pendekatan kuantitatif, dimana metode penelitian yang berdasarkan pada falsafah positivisme. Penelitian kuantitaif ini digunakan untuk meneliti pada populasi atau sampel tertentu, teknik pengambilan sempel penelitian kuantitatif pada umumnya dilakukan secara acak, pengumpulan data menggunakan instrumen penelitian, analisis data bersifat kuantitatif/statistik dengan tujuan untuk menguji hasil sementara yang telah ditetapkan. ${ }^{12}$

\section{Lokasi Penelitian}

Adapun objek atau lokasi penelitian adalah BRISyariah KCP Genteng Kabupaten Banyuwangi.

\section{Sumber data}

Sumber data berasal dari dua sumber yaitu:

a. Data primer adalah sumber data penelitian yang diperoleh secara langsung dari sumber aslinya. Dalam penelitian ini berupa jawabanjawaban yang diperoleh melalui wawancara, jajak pendapat dari individu atau kelompok (orang) melalui angket/kuesioner yang disebarkan maupun hasil observasi dari suatu obyek dalam hal ini data primer bersumber dari nasabah tabungan haji di BRISyariah KCP Genteng.

b. Data sekunder adalah data penelitian yang diperoleh secara tidak langsung. Data sekunder dapat diperoleh dari dokumen-dokumen BRISyariah KCP Genteng, penelitian terdahulu, jurnal dan buku-buku yang berkaitan dengan penelitian ini.

${ }^{12}$ Sugiyono. 2013. Metode Penelitian Pendidikan Pendekatan Kuantitatif, Kualitatif, dan $R \& D$. Bandung: Alfabeta. Hal 15 


\section{Teknik Pengumpulan Data(jelaskan lebih detail)}

a. Observasi

Peneliti menggunakan tipe observasi nonpartisipan yaitu peneliti tidak terlibat dan sebagai pengamat independen. Observasi ini dilakukan di BRISyariah KCP Genteng.

b. Interview (Wawancara)

Wawancara ini bertujuan untuk mengetahui sejauh mana strategi pemasaran yang dilakukan oleh pikah perbankan dalam memasarkan produk tabungan haji serta bagaimana pengaruh waiting list terhadap calon jamaah haji.

c. Dokumentasi

Metode dokumentasi adalah mencari data mengenai hal-hal atau variabel yang berupa catatan, transkip, buku, surat kabar, majalah, prasasti, notulen rapat, leger dan agenda dan sebagainya. Metode ini penulis gunakan untuk mencari dan memperoleh data tentang hal-hal yang berkaitan dengan penelitian yang sifatnya dokumenter yang meliputi data jumlah nasabah, sejarah, logo dan struktur organisani Bank BRISyariah.

d. Kuesioner (Angket)

Kuesioner merupakan teknik pengumpulan data yang dilakukan dengan cara memberi seperangkat pertanyaan atau pertanyaan tertulis kepada responden untuk dijawab. ${ }^{13}$ Responden dalam penelitian ini sebanyak 30 orang nasabah tabungan haji di BRISyariah KCP Genteng. Pengukuran variabel dilakukan dengan skala Likert terhadap pertanyaan dengan gradasi sangat positif sampai dengan sangat negatif. Penskalaan adalah proses menetapkan nomor-nomor atau simbol-simbol terhadap suatu atribut atau karakteristik yang bertujuan untuk mengukur atribut atau karakteristik tersebut. Adapun skor yang diberikan adalah sebagai berikut:

\footnotetext{
${ }^{13}$ Sugiyono, 2016. Metode Penelitian Kuantitatfi, kualitatif dan R\&D. Alfabeta. Bandung. Hal 142
} 

a. $\quad$ SS (sangat setuju $)=5$
b. $\quad S($ setuju $)=4$
c. Netral $=3$
d. $\quad$ TS $($ tidak setuju $)=2$
e. STS $($ sangat tidak setuju $)=1$

\section{Alat Analisis Data}

Teknik analisis data pada penelitian ini menggunkan teknik analisis regresi linier berganda yang terdiri dari 2 (dua) variabel independen yaitu variabel strategi pemasaran syariah $\left(\mathrm{X}_{1}\right)$ dan waiting list $\left(\mathrm{X}_{2}\right)$ dan 1 (satu) variabel dependen yaitu variabel keputusan nasabah (Y) menggunakan produk tabungan haji pada BRISyariah KCP Genteng kabupaten Banyuwangi. Persamaan regresi linier berganda dapat dituliskan sebagai berikut:

$$
\mathbf{Y}=\mathbf{a}+\mathbf{b}_{1} \mathbf{X}_{1}+\mathbf{b}_{2} \mathbf{X}_{2}+\ldots .+b_{n} \mathbf{X n}+\varepsilon
$$

Keterangan:

Y : Variabel tergantung

a : Bilangan konstanta

$b_{1}$ : Koefisien regresi untuk X1

$b_{2}$ : Koefisien regresi untuk X2

bn : Koefisien regresi untuk Xn

$\mathrm{X}_{1}$ : Variabel bebas pertama

$\mathrm{X}_{2}$ : Variabel bebas kedua

$\mathrm{Xn}$ : Variabel bebas ke $\mathrm{n}$

$\varepsilon \quad$ : Nilai residu

Dengan analisis regresi berganda ini juga dapat diketahui variabel mana diantara variabel independen yaitu yang berpengaruh dominan terhadap variabel dependen yaitu strategi pemasaran syariah $\left(\mathrm{X}_{1}\right)$ dan waiting list $\left(\mathrm{X}_{2}\right)$ terhadap keputusan nasabah (Y) menggunakan produk tabungan haji di BRISyariah KCP Genteng kabupaten Banyuwangi. Analisis regresi linier 
berganda juga dapat digunakan untuk mengetahui seberapa besar hubungan masing-masing independen terhadap variabel independen lainnya.

\section{Hasil Penelitian}

\section{a. Uji Validitas}

Dalam penelitian ini uji validitas yang digunakan adalah dengan menggunakan rumus pearson product moment. Untuk menguji validitas alat ukur, terlebih dahulu dicari harga korelasi setiap bagian dari alat ukur secara keseluruhan dengan cara mengkorelasikan setiap butir alat ukur dengan skor total yang merupakan jumlah tiap skor butir. Adapun hasil dari rumus pearson product moment adalah sebagai berikut:

Tabel 4.1 Hasil Uji Validitas Strategi Pemasaran $\left(X_{1}\right)$

\begin{tabular}{|c|c|c|c|c|}
\hline $\begin{array}{c}\text { No. Item } \\
\text { Pertanyaan }\end{array}$ & $\begin{array}{c}\text { Koefesien Korelasi } \\
\text { rhitung }\end{array}$ & $\begin{array}{c}\text { Harga } \\
\text { thitung }\end{array}$ & $\begin{array}{c}\text { Harga } \\
\text { ttabel }\end{array}$ & Keputusan \\
\hline $\mathbf{1}$ & 0,6 & 3,99 & 2,04 & Valid \\
\hline $\mathbf{2}$ & 0,73 & 5,68 & 2,04 & Valid \\
\hline $\mathbf{3}$ & 0,5 & 3,02 & 2,04 & Valid \\
\hline $\mathbf{4}$ & 0,67 & 4,72 & 2,04 & Valid \\
\hline $\mathbf{5}$ & 0,56 & 3,61 & 2,04 & Valid \\
\hline $\mathbf{6}$ & 0,73 & 5,7 & 2,04 & Valid \\
\hline $\mathbf{7}$ & 0,52 & 3,22 & 2,04 & Valid \\
\hline $\mathbf{8}$ & 0,71 & 5,39 & 2,04 & Valid \\
\hline $\mathbf{9}$ & 0,66 & 4,62 & 2,04 & Valid \\
\hline $\mathbf{1 0}$ & 0,48 & 2,92 & 2,04 & Valid \\
\hline
\end{tabular}

Sumber : Data diolah peneliti, 2019

Berdasarkan hasil perhitungan pearson product moment pada Tabel 4.1 di atas setelah mendapatkan data penelitian dengan cara penyebaran angket kepada nasabah tabungan haji diketahui bahwa dari 10 pernyataan yang diberikan mengenai strategi pemasaran pada BRISyariah KCP Genteng menunjukkan bahwa seluruh pernyataan dinyatakan valid. Hal ini dikarenakan semua harga thitung strategi pemasaran lebih besar dari pada $t_{\text {tabel. }}$ 
Tabel 4.2 Hasil Uji Validitas Waiting list $\left(\mathrm{X}_{2}\right)$

\begin{tabular}{|c|c|c|c|c|}
\hline $\begin{array}{c}\text { No. Item } \\
\text { Pertanyaan }\end{array}$ & $\begin{array}{c}\text { Koefesien Korelasi } \\
\mathbf{r}_{\text {hitung }}\end{array}$ & $\begin{array}{c}\text { Harga } \\
\mathbf{t}_{\text {hitung }}\end{array}$ & $\begin{array}{c}\text { Harga } \\
\mathbf{t}_{\text {tabel }}\end{array}$ & Keputusan \\
\hline $\mathbf{1}$ & 0,39 & 2,21 & 2,04 & Valid \\
\hline $\mathbf{2}$ & 0,5 & 3,08 & 2,04 & Valid \\
\hline $\mathbf{3}$ & 0,54 & 3,39 & 2,04 & Valid \\
\hline $\mathbf{4}$ & 0,41 & 2,38 & 2,04 & Valid \\
\hline $\mathbf{5}$ & 0,62 & 4,16 & 2,04 & Valid \\
\hline $\mathbf{6}$ & 0,61 & 4,08 & 2,04 & Valid \\
\hline $\mathbf{7}$ & 0,57 & 3,68 & 2,04 & Valid \\
\hline $\mathbf{8}$ & 0,58 & 3,8 & 2,04 & Valid \\
\hline $\mathbf{9}$ & 0,61 & 4,08 & 2,04 & Valid \\
\hline $\mathbf{1 0}$ & 0,42 & 2,46 & 2,04 & Valid \\
\hline
\end{tabular}

Sumber : Data diolah peneliti, 2019

Berdasarkan hasil perhitungan pearson product moment pada tabel 4.2 di atas setelah mendapatkan data penelitian dengan cara penyebaran angket kepada nasabah tabungan haji diketahui bahwa dari 10 pernyataan yang diberikan mengenai waiting list pada BRISyariah KCP Genteng menunjukkan bahwa seluruh pernyataan dinyatakan valid. Hal ini dikarenakan semua harga $t_{\text {hitung }}$ waiting list lebih besar dari pada $t_{\text {tabel. }}$

Tabel 4.3 Hasil Uji Validitas Keputusan Nasabah (Y)

\begin{tabular}{|c|c|c|c|c|}
\hline $\begin{array}{c}\text { No. Item } \\
\text { Pertanyaan }\end{array}$ & $\begin{array}{c}\text { Koefesien Korelasi } \\
\mathbf{r}_{\text {hitung }}\end{array}$ & $\begin{array}{c}\text { Harga } \\
\mathbf{t}_{\text {hitung }}\end{array}$ & $\begin{array}{c}\text { Harga } \\
\mathbf{t}_{\text {tabel }}\end{array}$ & Keputusan \\
\hline $\mathbf{1}$ & 0,49 & 3 & 2,04 & Valid \\
\hline $\mathbf{2}$ & 0,77 & 6,39 & 2,04 & Valid \\
\hline $\mathbf{3}$ & 0,73 & 5,64 & 2,04 & Valid \\
\hline $\mathbf{4}$ & 0,77 & 6,39 & 2,04 & Valid \\
\hline $\mathbf{5}$ & 0,67 & 4,78 & 2,04 & Valid \\
\hline $\mathbf{6}$ & 0,49 & 2,97 & 2,04 & Valid \\
\hline $\mathbf{7}$ & 0,42 & 2,44 & 2,04 & Valid \\
\hline $\mathbf{8}$ & 0,62 & 4,14 & 2,04 & Valid \\
\hline $\mathbf{9}$ & 0,75 & 6,02 & 2,04 & Valid \\
\hline $\mathbf{1 0}$ & 0,68 & 4,85 & 2,04 & Valid \\
\hline
\end{tabular}

Sumber : Data diolah peneliti, 2019

Berdasarkan hasil perhitungan pearson product moment pada Tabel 4.3 di atas setelah mendapatkan data penelitian dengan cara penyebaran angket kepada nasabah tabungan haji diketahui bahwa dari 10 pernyataan yang diberikan mengenai keputusan nasabah pada BRI Syariah KCP Genteng menunjukkan bahwa seluruh pernyataan dinyatakan valid. Hal ini

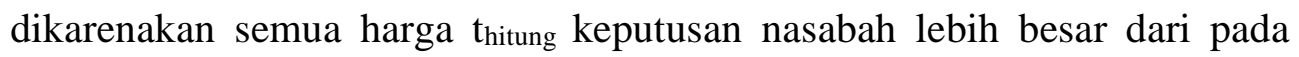
$t_{\text {tabel. }}$ 


\section{b. Uji Realibilitas}

Hasil pengujian reliabilitas dengan rumus product moment sebagai berikut:

Tabel 4.4 Hasil Uji Reliabilitas

\begin{tabular}{|c|c|c|c|c|c|}
\hline Variabel & Item & $\mathbf{R}_{\text {Hitung }}$ & $\mathbf{R}_{11}$ & $\mathbf{R}_{\text {tabel }}$ & Keterangan \\
\hline \multirow{10}{*}{$\begin{array}{c}\text { Strategi } \\
\text { Pemasaran }\left(X_{1}\right)\end{array}$} & $\mathrm{X}_{1.1}$ & 0,6 & \multirow{10}{*}{0,66} & \multirow{10}{*}{0,37} & Reliabel \\
\hline & $\mathrm{X}_{1.2}$ & 0,73 & & & Reliabel \\
\hline & $\mathrm{X}_{1.3}$ & 0,5 & & & Reliabel \\
\hline & $\mathrm{X}_{1.4}$ & 0,67 & & & Reliabel \\
\hline & $\mathrm{X}_{1.5}$ & 0,56 & & & Reliabel \\
\hline & $\mathrm{X}_{1.6}$ & 0,73 & & & Reliabel \\
\hline & $\mathrm{X}_{1.7}$ & 0,52 & & & Reliabel \\
\hline & $\mathrm{X}_{1.8}$ & 0,71 & & & Reliabel \\
\hline & $\mathrm{X}_{1.9}$ & 0,66 & & & Reliabel \\
\hline & $\mathrm{X}_{1.10}$ & 0,48 & & & Reliabel \\
\hline \multirow{10}{*}{ Waiting List $\left(\mathrm{X}_{2}\right)$} & $\mathrm{X}_{2.1}$ & 0,39 & \multirow{10}{*}{0,45} & \multirow{10}{*}{0,37} & Reliabel \\
\hline & $\mathrm{X}_{2.2}$ & 0,5 & & & Reliabel \\
\hline & $\mathrm{X}_{2.3}$ & 0,54 & & & Reliabel \\
\hline & $\mathrm{X}_{2.4}$ & 0,41 & & & Reliabel \\
\hline & $\mathrm{X}_{2.5}$ & 0,62 & & & Reliabel \\
\hline & $\mathrm{X}_{2.6}$ & 0,61 & & & Reliabel \\
\hline & $\mathrm{X}_{2.7}$ & 0,57 & & & Reliabel \\
\hline & $\mathrm{X}_{2.8}$ & 0,58 & & & Reliabel \\
\hline & $\mathrm{X}_{2.9}$ & 0,61 & & & Reliabel \\
\hline & $\mathrm{X}_{2.10}$ & 0,42 & & & Reliabel \\
\hline \multirow{10}{*}{$\begin{array}{l}\text { Keputusan } \\
\text { Nasabah (Y) }\end{array}$} & $\mathrm{Y}_{1}$ & 0,49 & \multirow{10}{*}{0,87} & \multirow{10}{*}{0,37} & Reliabel \\
\hline & $\mathrm{Y}_{2}$ & 0,77 & & & Reliabel \\
\hline & $\mathrm{Y}_{3}$ & 0,73 & & & Reliabel \\
\hline & $\mathrm{Y}_{4}$ & 0,77 & & & Reliabel \\
\hline & $\mathrm{Y}_{5}$ & 0,67 & & & Reliabel \\
\hline & $\mathrm{Y}_{6}$ & 0,49 & & & Reliabel \\
\hline & $\mathrm{Y}_{7}$ & 0,42 & & & Reliabel \\
\hline & $\mathrm{Y}_{8}$ & 0,62 & & & Reliabel \\
\hline & $\mathrm{Y}_{9}$ & 0,75 & & & Reliabel \\
\hline & $\mathrm{Y}_{10}$ & 0,68 & & & Reliabel \\
\hline
\end{tabular}

Sumber : Data diolah peneliti, 2019 
Pada keterangan sebelumnya, diketahui bahwa variabel strategi pemasaran, variabel waiting list, dan variabel keputusan nasabah yang sebelumnya telah diuji validitasnya menunjukkan bahwa dari 30 kuesionel pernyatan yang didapat dan telah dihitung dinyatakan valid. Kemudian dari 30 kuesioner yang telah valid tersebut diuji reliabelnya. Dari tabel 4.8 diatas menunjukkan bahwa semua harga $r_{11}>$ harga $r_{\text {tabel }}$. Maka dapat diambil kesimpulan bahwa semua variabel dinyatakan reliabel.

\section{c. Uji Normalitas}

Tabel 4.5 Hasil Uji Normalitas

\begin{tabular}{|l|l|r|}
\hline \multicolumn{2}{|l|}{} & $\begin{array}{c}\text { Unstandardized } \\
\text { Residual }\end{array}$ \\
\hline $\mathrm{N}$ & Mean & 30 \\
\hline \multirow{2}{*}{ Normal Parameters ${ }^{\mathrm{a}, \mathrm{b}}$} & Std. Deviation & 2,63403423 \\
\hline \multirow{3}{*}{ Most Extreme Differences } & Absolute & 0,071 \\
\cline { 2 - 3 } & Positive & 0,071 \\
\cline { 2 - 3 } & Negative & $-0,069$ \\
\hline Test Statistic & & 0,071 \\
\hline Asymp. Sig. (2-tailed) & & 0,2 \\
\hline
\end{tabular}

a. Test distribution is Normal.

b. Calculated from data.

c. Lilliefors Significance Correction.

$\mathrm{d}$. This is a lower bound of the true significance.

Sumber data diolah peneliti, 2019

Uji static kolmogorov-smirnov di atas, diketahui bahwa nilai asumsi signifikansi sebesar 0,2 yang mana lebih besar dari 0,05. Hal ini menunjukkan bahwa variabel strategi pemasaran, variabel waiting list dan vaariabel keputusan nasabah memiliki nilai residual berdistribusi normal.

\section{d. Analisis Regresi Linier Berganda}

\section{1) Uji Analisis Regresi Secara Parsial (t test)}

Uji $\mathrm{t}$ digunakan untuk mengetahui apakah masing-masing variabel independen yaitu strategi pemasaran dan waiting list berpengaruh atau tidak terhadap variabel dependen yatitu keputusan nasabah. 
Hipotesis :

$\mathrm{H}_{\mathrm{o}}$ : koefisien regresi tidak signifikan

$\mathrm{H}_{1}$ : Koefisien regresi signifikan

Tabel 4.6 Hasil Uji t

\begin{tabular}{|c|c|c|c|c|c|c|}
\hline \multicolumn{2}{|c}{ Model } & \multicolumn{2}{|c|}{$\begin{array}{c}\text { Unstandardized } \\
\text { Coefficients }\end{array}$} & $\begin{array}{c}\text { Standardized } \\
\text { Coefficients }\end{array}$ & \multirow{2}{*}{ t } & \multirow{2}{*}{ Sig. } \\
\cline { 2 - 7 } & B & Std. Error & Beta & & \\
\hline \multirow{3}{*}{1} & (Constant) & 11,41 & 7,688 & & 1,484 & 0,149 \\
\cline { 2 - 8 } & $\begin{array}{c}\text { strategi } \\
\text { pemasaran }\end{array}$ & 0,395 & 0,187 & 0,416 & 2,119 & 0,043 \\
\cline { 2 - 8 } & waiting list & 0,335 & 0,229 & 0,287 & 1,462 & 0,155 \\
\hline
\end{tabular}

a. Dependent Variable: keputusan nasabah Sumber data SPSS, 2019

Berdasarkan Tabel 4.6 dapat diketahui Unstandardized Coefficients (Constant) sebesar 11,41 yang artinya jika strategi pemasaran dan waiting list sama dengan 0, maka keputusan nasabah untuk menabung sebesar 11,41. Unstandardized Coefficients strategi pemasaran sebesar 0,395, artinya jika strategi pemasaran baik dan tepat maka akan naik sebesar 0,395. Unstandardized Coefficients waiting list sebesar 0,335 yang artinya jika waiting list berpengaruh, maka waiting list meningkat sebesar 0,335. Standart Error (Constant) sebesar 7,668 yang menunjukkan penyimpangan dari konstanta yang ada dalam model persamaan regresi. Std. Error strategi pemasaran sebesar 0,187 yang menunjukkan penyimpangan koefisien regresi variabel stratetgi pemasaran. Semakin kecil penyimpangan dalam koefisien regresi tersebut maka semakin berarti kontribusi variabel tersebut terhadap variabel tergantungnya. Std. Error waiting list sebesar 0,229 yang menunjukkan penyimpangan koefisien regresi variabel waitng list. Semakin kecil penyimpangan dalam koefisien regresi tersebut maka semakin berarti kontribusi variabel tersebut terhadap variabel tergantungnya. 


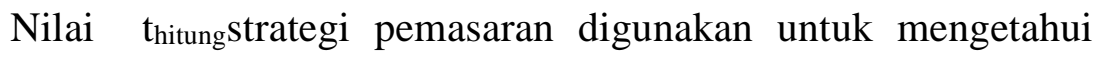
apakah variabel bebas tersebut signifikan atau tidak. Berdasarkan Tabel 4.10 diketahui t-strategi pemasaran sebesar 2,119. Sedangkan

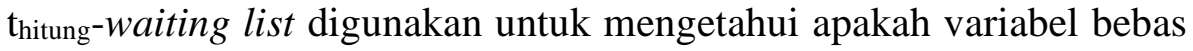
tersebut signifikan atau tidak. Berdasarkan Tabel 4.10 diketahui

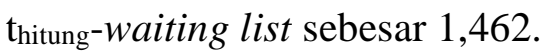

\section{2) Uji Simultan (F test)}

Uji $\mathrm{F}$ digunakan untuk menguji hipotesis mengenai variabel strategi pemasaran dan waiting list secara simultan atau bersama-sama berpengaruh positif dan signifikan terhadap variabel dependen yaitu keputusan nasabah tabungan haji di BRI Syariah KCP Genteng Banyuwangi. Adapun hasil uji f dapat dilihat pada tabel dibawah ini:

Tabel 4.7 Hasil Uji F

\begin{tabular}{|c|c|c|c|c|c|}
\hline Model & Sum of Squares & df & Mean Square & $\mathbf{F}$ & Sig. \\
\hline 1 Regression & 141,494 & 2 & 70,747 & 9,494 & 0,001 \\
\hline Residual & 201,206 & 27 & 7,452 & & \\
\hline Total & 342,700 & 29 & & & \\
\hline
\end{tabular}

a. Dependent Variable: keputusan nasabah

b. Predictors: (Constant), waiting list, strategi pemasaran

Sumber data SPSS, 2019

Berdasarkan Tabel 4.7 dapat diketahui Sum of Squares Regression sebesar 141,494 yang menunjukkan bahwa jumlah kuadrat dari dari selisih antara nilai perediksi dengan nilai rata-rata prediksi. Sum of Squares Residual sebesar 201,206 yang menunjukkan bahwa jumlah kuadrat dari dari selisih antara nilai riil dengan nilai prediksi. Sum of Squares Total sebesar 342,7 yang menunjukkan bahwa jumlah kuadrat dari dari selisih antara nilai riil dengan nilai rata-rata Y riil. Df Regression (Degree of Freedom Regression) sebesar 1. Hal ini karena nilai k-1, jumlah variabel dikurangi 1 (3- 
1=2). Df Residual (Degree of Freedom Residual) sebesar 27. Hal ini karena nilai n-k, jumlah pengamatan dikurangi jumlah variabel (303=27). Df Total (Degree of Freedom Total) sebesar 29. Hal ini karena nilai n-1, jumlah pengamatan dikurangi 1 (30-1=29). Mean Square Regression menunjukkan hasil pembagian dari Sum of Squares Regression dengan Degree of Freedom Regression sebesar 70,747. Mean Square Residual sebesar 7,542. F Fitung sebesar 9,494 dengan tingkat kesalahan atau probabilitas sebesar 0,001 berarti lebih kecil dari 0,05. Jadi bisa disimpulkan bahwa variabel bebas secara simultan mampu menjelaskan perubahan pada variabel tergantung atau model dinyatakan cocok.

\section{3) Uji Koefisien Determinasi (R Square)}

Kemudian untuk mengetahui seberapa besar pengaruh atau kontribusi yang diberikan oleh $\mathrm{X}_{1}$ dan $\mathrm{X}_{2}$ kepada $\mathrm{Y}$ secara simultan maka, bisa dilihat pada uji koefesien determinan pada data summary. Adapun pengaruh yang diberikan adalah sebagai berikut :

Tabel 4.8 Hasil Uji Koefesien Determinasi

\begin{tabular}{|l|r|r|r|r|}
\hline Model & $\mathrm{R}$ & $\mathrm{R}$ Square & \multicolumn{1}{c|}{$\begin{array}{c}\text { Adjusted R } \\
\text { Square }\end{array}$} & $\begin{array}{l}\text { Std. Error of the } \\
\text { Estimate }\end{array}$ \\
\hline 1 & 0,643 & 0,413 & 0,369 & 2,729 \\
\hline
\end{tabular}

a. Predictors: (Constant), waiting list, strategi pemasaran Sumber data SPSS, 2019

Berdasarkan Tabel 4.8 dapat diketahui $\mathrm{R}$ atau multiple sebesar 0,643 yang menunjukkan korelasi antara variabel bebas dengan variabel tergantung. Karena dalam regresi linier berganda terdapat dua variabel, maka korelasi antara stratetgi pemasaran dan waiting list terhadap keputusan nasabah adalah sebesar 0,643. Besar R Square adalah 0,413 yang menunjukkan bahwa variabel stratetgi pemasaran dan waiting list memengaruhi sebesar $41,3 \%$. Adjusted $R$ Square menunjukkan koefisien determinasi yang telah dijumlah dengan varian dan ukuran sampel sehingga dapat mengurangi unsur jika 
terjadi penambahan variabel ukuran sampel. Besar Adjusted R Square 0,369 yang berarti variasi keputusan nasabah dijelaskan oleh variasi stratetgi pemasaran dan waiting list sebesar 36,9\%. Std. Error of the Estimate adalah penyimpangan antara persamaan regresi dengan dependen riilnya, yaitu sebesar 2,729 satuan variabel dependen (jika keputusan nasabah dihitung dalam satuan, maka besarnya penyimpangan adalah 2,729 juta). Semakin kecil nilai standard, maka semakin baik persamaan regresi tersebut sebagai alat prediksi.

\section{Pembahasan}

a. Berdasarkan hasil analisis regresi, diperoleh nilai $t_{\text {hitung }}$ sebesar 2,119 $>t_{\text {tabel }}$ 2,04 dan nilai signifikansi (sig) $0,043<0,05$. Maka dapat disimpulkan bahwa $\mathrm{H}_{\mathrm{a}}$ diterima dan $\mathrm{H}_{0}$ ditolak yang berarti bahwa strategi pemasaran $\left(\mathrm{X}_{1}\right)$ berpengaruh positif dan signifikan terhadap keputusan nasabah $(\mathrm{Y})$.

b. Berdasarkan hasil analisis regresi, diperoleh nilai $t_{\text {hitung }}$ sebesar 1,462 < $\mathrm{t}_{\text {tabel }}$ 2,04 dan nilai signifikansi (sig) 0,155 > 0,05. Maka dapat disimpulkan bahwa $\mathrm{H}_{\mathrm{a}}$ ditolak dan $\mathrm{H}_{0}$ diterima yang berarti bahwa waiting list $\left(\mathrm{X}_{2}\right)$ tidak berpengaruh positif dan signifikan terhadap keputusan nasabah (Y).

c. Penelitian yang dilakukan di BRISyariah KCP Genteng Banyuwangi telah memperoleh hasil pengolahan data statistik yang menunjukkan adanya pengaruh antara variabel independen, strategi pemasaran $\left(\mathrm{X}_{1}\right)$ dan waiting list $\left(\mathrm{X}_{2}\right)$ terhadap variabel dependen keputusan nasabah $(\mathrm{Y})$ menggunakan produk tabungan haji di BRISyariah Kcp Genteng Banyuwangi. Uji hipotesis secara bersama-sama atau simultan dinotasikan dalam uji $\mathrm{F}$ yang menyatakan bahwa terdapat pengaruh signifikan secara simultan antara variabel strategi pemasaran $\left(\mathrm{X}_{1}\right)$ dan waiting list $\left(\mathrm{X}_{2}\right)$ terhadap variabel dependen yaitu keputusan nasabah (Y) menggunakan tabungan haji pada BRISyariah KCP Genteng Banyuwangi.

Nilai $F_{\text {hitung }}$ sebesar 9,494 yang mana lebih besar dari pada $F_{\text {tabel }}$ 3,35 dan nilai signifikansi (sig) $0,001<0,05$, maka dapat disimpulkan bahwa $\mathrm{H}_{\mathrm{a}}$ 
diterima dan $\mathrm{H}_{0}$ ditolak, yang artinya variabel strategi pemasaran $\left(\mathrm{X}_{1}\right)$ dan waiting list $\left(\mathrm{X}_{2}\right)$ secara simultan berpengaruh positif dan signifikan terhadap variabel keputusan nasabah (Y) menggunakan tabungan haji pada BRISyariah KCP Genteng Banyuwangi.

Nilai koefesien determinasi $\left(\mathrm{R}^{2}\right)$ sebesar 0,413. Hari hasil tersebut menunjukkan bahwa pengaruh variabel strategi pemasaran dan waiting list secara simultan terhadap variabel keputusan nasabah sebesar 41,3\%. Sedangkan untuk sisanya yaitu sebesar $58,7 \%$ dipengaruhi oleh variabelvariabel lainnya yang tidak diteliti dalam penelitian ini.

\section{Kesimpulan}

Dari penjelasan di atas, berikut ini adalah kesimpulan yang dapat diambil dalam penelitian ini:

a. Terdapat pengaruh signifikan secara parsial antara variabel strategi pemasaran $\left(\mathrm{X}_{1}\right)$ terhadap variabel keputusan nasabah $(\mathrm{Y})$ menggunakan tabungan haji di BRISyariah KCP Genteng Banyuwangi.

b. Tidak terdapat pengaruh secara parsial antara variabel waiting list $\left(\mathrm{X}_{2}\right)$ terhadap variabel keputusan nasabah (Y) menggunakan tabungan haji di BRISyariah KCP Genteng Banyuwangi.

c. Terdapat pengaruh signifikan secara simultan antara variabel strategi pemasaran $\left(\mathrm{X}_{1}\right)$ dan variabel waitng list $\left(\mathrm{X}_{2}\right)$ terhadap variabel keputusan nasabah (Y) menggunakan tabungan haji di BRISyariah KCP Genteng Banyuwangi.

\section{Daftar Pustaka}

Ardiastuti, Wiji. T: 2017. Strategi Pemasaran Tabungan Haji Di Bank Rakyat Indonesia Syariah Kcp Ajibarang. Purwokerto: Fakultas Ekonomi dan Bisnis Islam IAIN Purwokerto.

Daulay, Aqwa Naser. 2017. Faktor-Faktor Yang Berhubungan Dengan Perkembangan Produk Tabungan Haji Perbankan Syariah Di Indonesia Human Falah. Sumatra Utara. Fakultas Ekonomi dan Bisnis Islam UIN Sumatra Utara. 
Dewi, Rida Arista. 2018. Pengaruh Pendapatan, Religiuistas dan Daftar Tunggu Haji Terhadap Minat Santri Untuk Menabung Tabungan Haji dengan Pendekatan Theory of Planned Behavior. Skripsi. Yogyakarta: Fakultas Ekonomi dan Bisnis Islam UIN Sunan Kalijaga Yogyakarta.

Ermawati. 2018. Analisis Dampak Implementasi Produk Tabungan Haji Mabrur Terhadap Waiting List Ibadah Haji. Skripsi. Lampung: Fakultas Ekonomi dan Bisnis Islam UIN Raden Intan Lampung.

Fandy Tjiptono. 2015. Strategi Pemasaran. Yagyakarta: Penerbit Andi. Hal. 2

Kotler, Philip, dan Gary Armstrong. 2012. Prinsip-prinsip Pemasaran, Edisi 13 Jilid 1. Jakarta: Penerbit Erlangga.

Kotler, Philip dan Keller, K.L. 2016. Manajemen Pemasaran, Edisi 13 Jilid 1. Jakarta: Penerbit Erlangga.

Sugiyono, 2016. Metode Penelitian Kuantitatfi, kualitatif dan R\&D. Alfabeta. Bandung

Sugiyono, 2018. Metode Penelitian Kuantitatif. Bandung: Alfabeta.

Tajudin, Makdaleva, Hanura., Mulazid, Ade, Sofyan. 2017. Pengaruh Promosi, Kepercayaan Dan Kesadaran Merek Terhadap Keputusan Nasabah Menggunakan Produk Tabungan Haji (Mabrur) Bank Syariah Mandiri Kcp. Sawangan Kota Depok Jurnal Ekonomi Islam.

Tim BRISyariah. 2019. Profil BRISyariah Indonesia. (online) www.BRISyariah.com (Diakses tanggal 21 Maret 2019). 